\title{
CONSIDERACIONES EN TORNO A LA TÉCNICA DE LA ENCÁUSTICA GRECORROMANA
}

\author{
POR \\ JOSÉ Y JORGE CUNÍ
}

\begin{abstract}
RESUMEN
Los resultados obtenidos en el estudio analítico de algunas muestras de pintura mural romanas procedentes de Mérida parecen indicar que la materia pictórica empleada estaba compuesta por una mezcla de pigmentos y calcita aglutinados por una emulsión de cera de abejas y jabón potásico. Similares componentes fueron detectados también en otras muestras de pintura mural romana de Marsala y Complutum analizadas en este estudio.

El examen de los textos griegos y latinos sobre pintura parece confirmar que tanto la composición como las caracteristicas de la emulsión detectada corresponden a las de la técnica grecorromana de la encáustica, cuya composición exacta no ha sido detectada hasta la fecha y continúa siendo objeto de debate.
\end{abstract}

\section{SUMMARY}

The analytical study of a number of samples of Roman mural painting from Mérida strongly suggetst that the painting material used was composed of a mixture of pigments and calcite, and bound by an emulsion of beeswax and potassium soap. These ingredients were also identified in other samples of Greco-Roman mural painting from Marsala and Complutum.

Examination of Greek and Latin texts about painting appear to confirm that both the composition and the characteristics of the wax-and-soap emulsion detected are those of Greco-Roman encaustique technique, the precise formula of which has not yet been determined and is still the subject of debate.

\section{INTRODUCCIÓN}

Los murales romanos de Mérida presentan una serie de peculiaridades en su ejecución que difícilmente se explican sin la intervención de algún aglutinante orgánico en la fijación de los 
pigmentos: fondos de color bruñidos y densos; gruesos empastes, de aspecto bien diferente a los del fresco realizados con cal: superposicion de múltiples estratos pictoricos. que aparecen en seccion nitidamente separados (figs. 1 y 2): presencia de epontates y ausencia de "giornate".

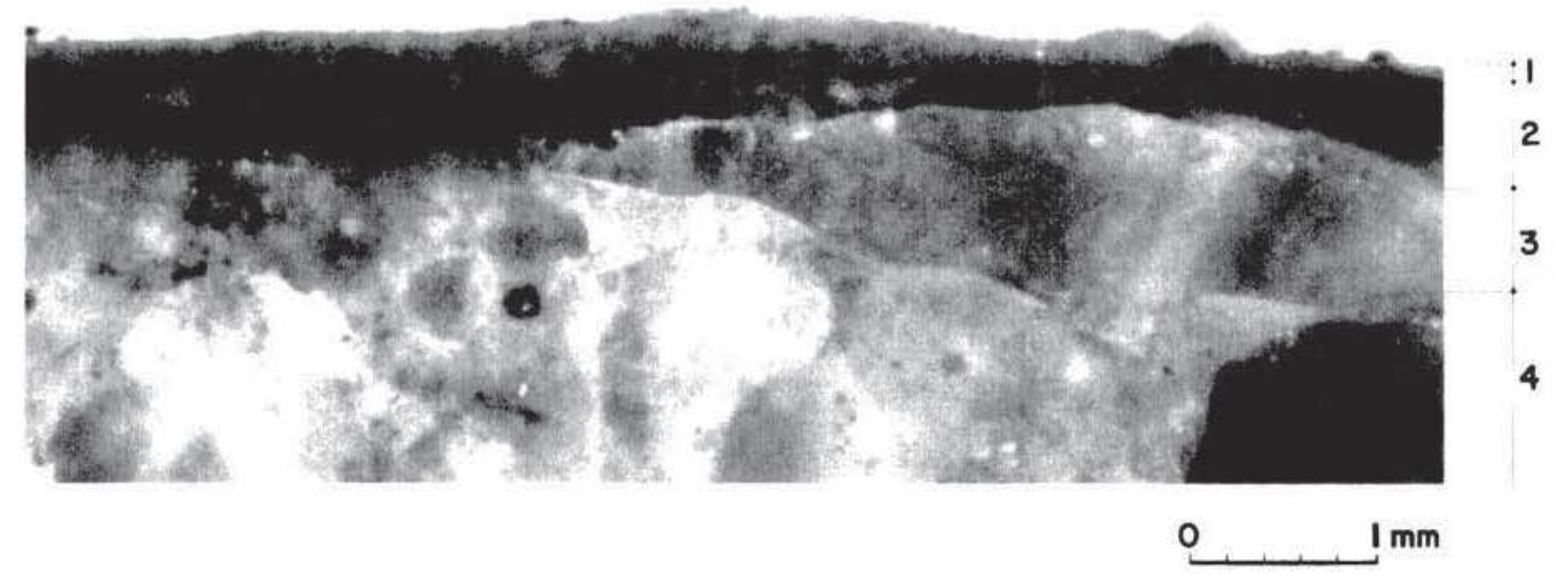

Figura 1. Fstratigrafia de la muestra Merida 1. 1: Capa de pintura verde claro, 2: Capa de fondo marron oscuro. 3: Particula de silice 4: Mortero. Se observa la capa de pintura marron aplicada tanto sobre el mortero poroso, que aparece impregnado de color. como sobre una particula de silice que impediria la adherencia de los pigmentos si no estuvieran aglutinados por un medio orgánico. E:1 corte recto con la capa verde indica que el estrato marron ha sido fuertemente bruñido. La capa superior, siguiendo la regla general en Mérida, no ha sufrido brunido.

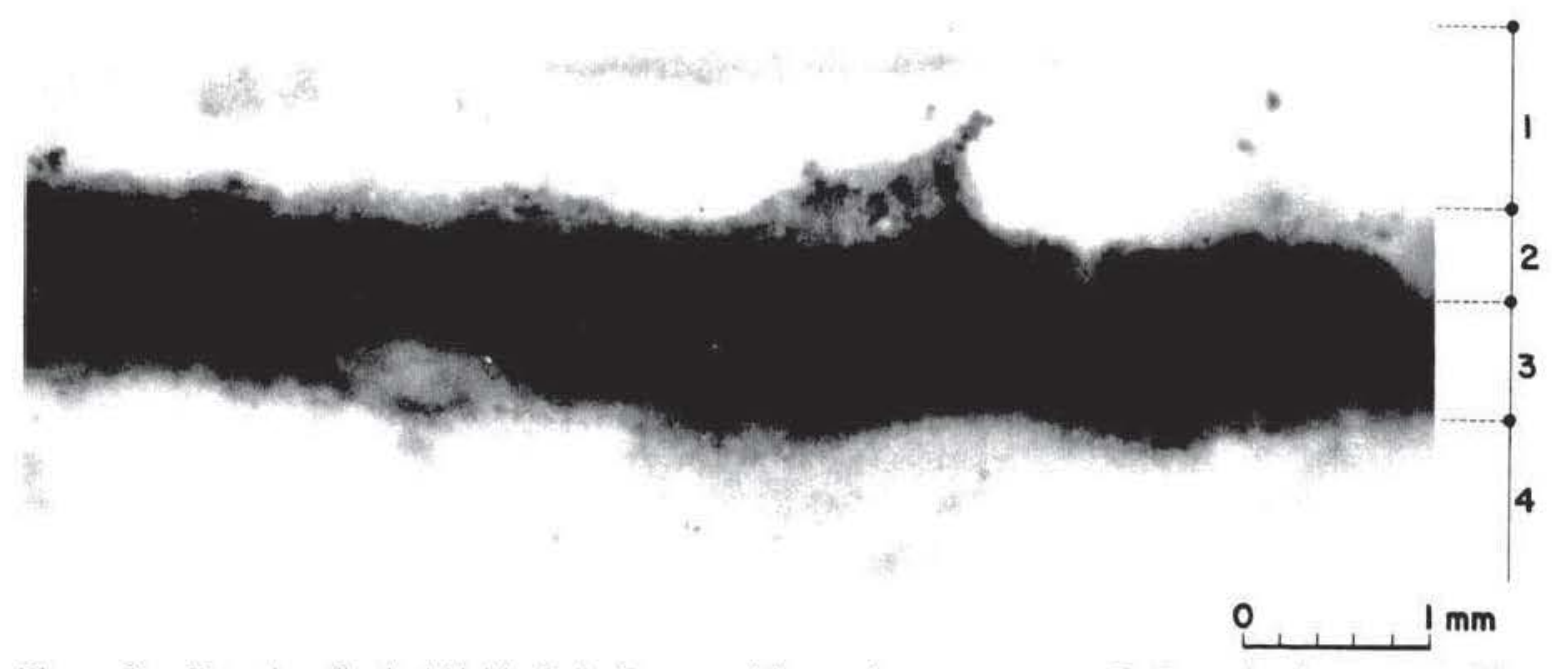

Figura 2, Estratigrafia de Mérida 2. I: Empaste blanco de gran espesor. 2: Capa de pintura amarilla.

3: Capa de pintura negra. 4: Fondo de pigmento negro mezclado con grandes cristales de azul egipcio. 5: Mortero. La capa de fondo ha penetrado parcialmente en el mortero indicando que la pintura fue aplicada muy diluida. Posteriormente fue bruñida. Luego fueron aplicadas las veladuras negra y amarilla, y finalmente el empaste blanco. 
Por otra parte, los colores de los murales de Mérida resultaban excesivamente vivos y brillantes para haber sido aglutinados con cal, y además el brillo aumentaba cuando la pintura era cepillada. Finalmente, la pintura se disolvia al frotarla con un trapo húmedo. Estas peculiaridades hicieron pensar a algunos especialistas que en la ejecución de los murales de Mérida debia haber intervenido algún tipo de temple'.

Parecia pues conveniente llevar a cabo una serie de análisis químicos que nos permitiera aproximarnos a la naturaleza del aglutinante empleado.

Las piezas objeto de este estudio fueron cuatro fragmentos de pintura mural de considerables dimensiones, procedentes de la "casa del mitreo" y de las "casas de la cripta del museo». Las muestras no habian sufrido ningún tratamiento de limpieza o protección y presentaban un magnífico estado de conservación.

\section{MÉTODOS INSTRUMENTALES}

Las muestras fueron sometidas a un análisis preliminar por espectrometría infrarroja para asegurar que carecian de sustancias orgánicas no detectables por cromatografía de gases, y que sirviera también para determinar el proceso de derivatización más apropiado para identificar los componentes presentes. Las muestras fueron montadas en una célula de microdiamante y analizadas con un Mattson Cygnus 100 Fourier-Transform Infrared Spectrophotometer/Spectratech IR-plan microscope.

Los análisis de infrarrojos detectaron básicamente hidrocarburos y ésteres (fig. 3), por lo que nos inclinamos por un método cromatográfico basado en el Derivation Method I desarrollado en C.A.L. para la identificación de ceras, aceites y resinas ${ }^{2}$.

La disolución del aglutinante, necesaria para su posterior examen por cromatografia de gases, resultó mucho más problemática de lo esperado. Se ensayaron diversas técnicas de extracción, pero los análisis cromatográficos y de infrarrojos, asi como los exámenes microscópicos, mostraban su escasa efectividad. Finalmente fue necesario recurrir a grandes muestras (hasta $1 \mathrm{~cm}^{2}$ ), y forzar la sensibilidad del cromatógrafo al máximo, con las desventajas asociadas de obtención de grandes picos debidos a contaminantes y una línea base con mucho ruido.

Los estratos pictóricos eran separados del soporte con un escalpelo, molidos en mortero de ágata y disueltos en agua. El vial con la pintura en suspensión era introducido en un baño de ultrasonidos durante dos horas. Tras centrifugación, los pigmentos y el resto de la materia inorgánica eran eliminados.

La solución era entonces tratada con varias gotas de $3 \mathrm{~N} \mathrm{HC1}$. Los compuestos orgánicos eran extraídos con éter, y éste posteriormente evaporado. Diez microlitros de cloruro metílico eran añadidos para disolver la muestra. El disolvente era parcialmente evaporado para concentrar la muestra, y la solución era entonces analizada por cromatografia de gases, los cromatógrafos utilizados fueron un Hewlett-Packard 5790A con un Integrator HP3394A, y un Carlo Erba HRGC 5300 Megaseries con un PE Nelson 900 series Interface.

\footnotetext{
1 Abad Casal, L., 1982: La Pintura Romana en España. Universidades de Alicante y Sevilla. I, 284.

${ }^{2}$ Erhardt, D., Hopwood., Baker, M., von Endt, D., 1988: A Systematic Approach to the Instrumental Analysis of Natural Finishes and Binding Media. New Orleans Conference of the American Institute for Conservation.
} 


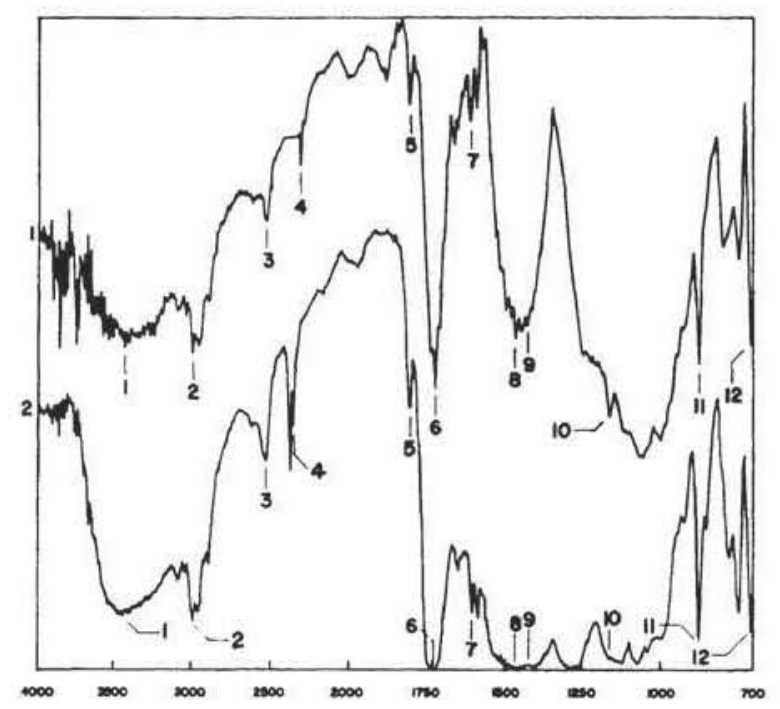

$\begin{array}{cll}\text { Banda } & \begin{array}{l}\text { Número } \\ \text { de onda }(\mathrm{cm} ~ ')\end{array} & \begin{array}{l}\text { Compuestos } \\ \text { Carbonato cálcico } \\ 1\end{array} \\ 2 & 3420 & \text { Hidrocarburos } \\ 3 & 2528 & \text { Carbonato cálcico } \\ 4 & 2320 & \text { Sales de ácidos grasos } \\ 5 & 1795 & \text { Carbonato cálcico } \\ 6 & 1730 & \text { Ésteres } \\ 7 & 1610 & \text { Sales de ácidos grasos } \\ 8 & 1464 & \text { Hidrocarburos } \\ 9 & 1427 & \text { Carbonato cálcico } \\ 10 & 1177 & \text { Ésteres } \\ 11 & 874 & \text { Carbonato cálcico } \\ 12 & 720 & \text { Hidrocarburos de cadena } \\ & & \text { larga }\end{array}$

Figura 3.-Espectro de infrarrojos. 1: Capa verde claro de la fig. 1. Muestra la presencia de carbonato cálcico, hidrocarburos, ésteres y jabones. 2: Espectro de infrarrojos de la capa marrón de la fig. 1. Este estrato pictórico inferior también indica presencia de hidrocarburos, ésteres y jabones, asi como de carbonato cálcico.

\section{RESULTADOS Y DISCUSIÓN}

Los cromatogramas de cada uno de los estratos pictóricos presentes en las cuatro muestras estudiadas mostraban un grupo de hidrocarburos de la serie impar C21-C31, con un máximo para C27, y un grupo de monoésteres de cadena larga de número par de carbonos C38-C50 en áreas decrecientes, en una configuración típica de la cera de abejas (fig. 4.1).

Los cromatogramas también revelaban presencia de ácidos grasos libres, así como algunos picos que no pudieron ser adscritos a ninguno de los materiales tradicionalmente asociados con procedimientos pictóricos antiguos y que fueron atribuidos a contaminaciones.

Los ácidos grasos detectados eran básicamente palmítico, esteárico y oleico, que procederían de grasas animales o aceites vegetales.

Como cabían dudas acerca del estado original en que dichas grasas o aceites habrían sido incorporados a la pintura, los análisis se repitieron pero prescindiendo del tratamiento de las muestras con ácido clorhídrido. En esta ocasión los cromatogramas revelaron un fuerte descenso en la proporción de ácidos grasos libres. Esto parecía indicar que la mayoría de los ácidos grasos de la muestra estaban saponificados, y por tanto no eran detectados por el cromatógrafo. El tratamiento con $\mathrm{HCl}$ los convertía en ácidos grasos libres y aparecían entonces en los cromatogramas (figs. 4.4 y 4.5 ).

Las muestras fueron analizadas una vez más tras tratar el aglutinante original con varias gotas de $\mathrm{KOH}$ al $10 \%$ en metanol y neutralizarlo posteriormente con varias gotas de $3 \mathrm{~N} \mathrm{HCl}$. Los ácidos grasos aparecieron con distribución y proporciones similares a los registrados la primera vez. Esto parecía corroborar que la materia grasa detectada en la pintura se encontraba saponificada originalmente, pues los ácidos aparecían libres de sus enlaces en los ésteres, y por este motivo podían ser detectados. 


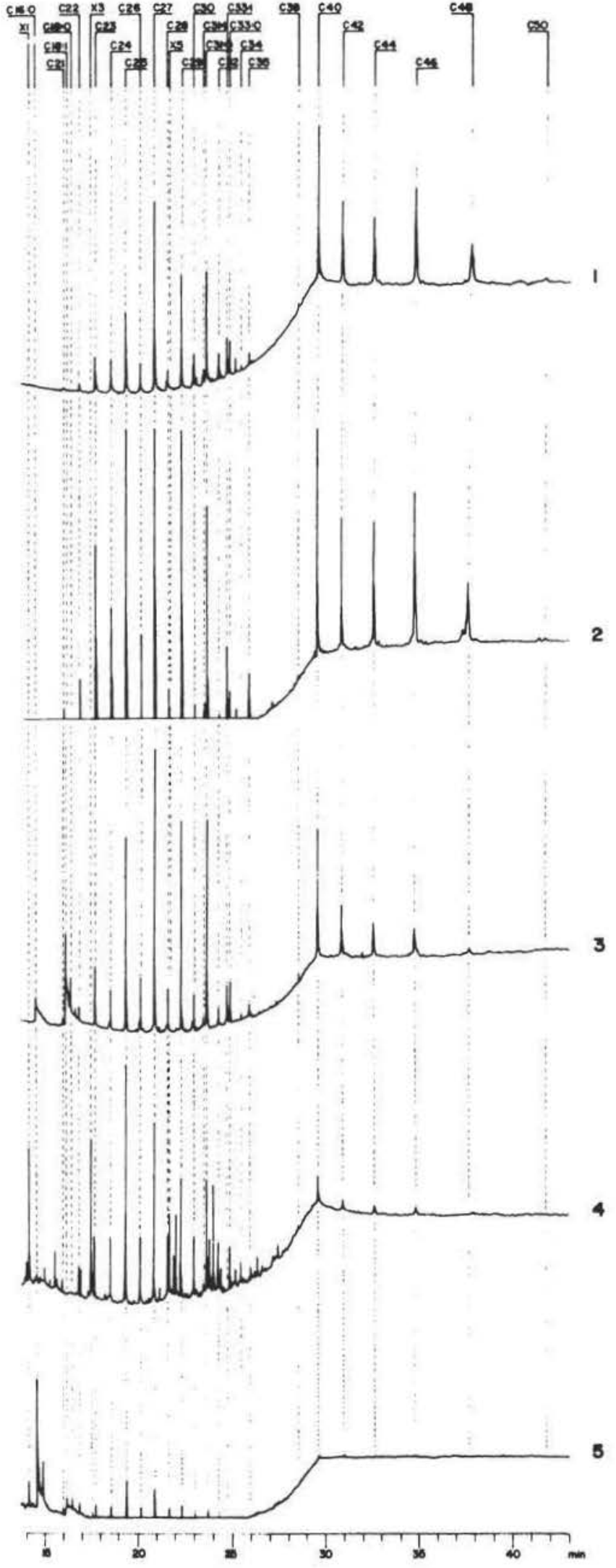

Picos

C16:0, C18:0, C18:1 Ácidos grasos libres. $\mathrm{C} 21-\mathrm{C} 35$ C38-C50

$\mathrm{X} 1, \mathrm{X} 2, \mathrm{X} 3, \mathrm{X} 5$

$\mathrm{X} 4$
Hidrocarburos.

Monoésteres de cadena larga.

Posible contaminación -no identificada.

Dioctileftalato - contaminación.

Figura 4.-Cromatogramas. 1: Cera blanca de abejas. 2: Cera blanca de abejas tratada con $\mathrm{KOH}$. 3: Emulsión de cera de abejas y aceite de oliva. Muestra tratada con $\mathrm{HCl}$. Los ácidos grasos del jabón aparecen sumados a la configuración de picos de la cera de abejas. 4: Análisis del empaste blanco de la fig. 2.1 disuelto en agua y sin tratar con $\mathrm{HCl}$. Cromatograma ruidoso y con contaminaciones, pero en el que se aprecian los picos de hidrocarburos y ésteres de la cera de abejas y una cantidad poco significativa de ácidos grasos. 5: La misma muestra de la figura anterior disuelta en agua y tratada con $\mathrm{HCl}$. $\mathrm{La}$ configuración de hidrocarburos y ésteres es sensiblemente similar a la anterior, pero la proporción de ácidos grasos ha aumentado de forma notable. 
Como experimento adicional en la detección de jabones se llevó a cabo una prueba para separar los productos hidrofilicos de los lipofilicos en las muestras Mérida 1 y Mérida 2. Los componentes orgánicos fueron disueltos en $\mathrm{CH}_{2} \mathrm{Cl}_{2}$ y extraídos. Una vez evaporado el disolvente, las fases etérea y acuosa fueron separadas con éter y agua. Los cromatogramas de ambas fases mostraron que los mismos componentes que aparecian en la fase etérea se encontraban también presentes en la fase acuosa. Ello sugería la presencia de un fuerte emulgente que impedia la correcta separación de las fases.

Se planteó la duda acerca de las responsabilidad de la causticidad del mortero de cal en la saponificación de los ácidos grasos. Se llevaron entonces a cabo ensayos de aglutinantes compuestos por cera de abejas y diversos aceites no secantes o grasas. Se comprobó que las mezclas no secaban, y por tanto no podían haber sido utilizadas como material artístico.

Si los ácidos grasos procedieran de aceites secantes estariamos ante un óleo con adición de cera, procedimiento que no aparece desarrollado hasta épocas muy posteriores ${ }^{3}$. Además un aglutinante de este tipo polimeriza, con lo que no se explicaría la solubilidad en agua que presentaban las muestras de Mérida.

\section{ENSAYOS EXPERIMENTALES}

Una serie de ensayos ha permitido determinar las caracteristicas y el comportamiento de la emulsión de cera y jabón como material artístico.

El jabón es un fuerte emulgente, elaborado desde la Antigüedad calentando grasas y aceites con lejías ${ }^{4}$. Si éstas eran sódicas, el jabón resultante era sólido. Las lejías potásicas, obtenidas tradicionalmente por filtración de agua hirviendo a través de diversas cenizas vegetales ${ }^{5}$, da lugar a un jabón de consistencia plástica.

A través de los ensayos experimentales se observó que la mezcla de jabón con cera de abejas fundida formaba una emulsión que podía ser diluida con agua en cualquier proporción.

Las moléculas de jabón se pueden explicar esquemáticamente como compuestas por una cabeza hidrofilica y una cola hidrofóbica. Al combinarlas con cera y agua, las colas parafinosas de dichas moléculas se adhieren a las partículas de cera, y las cabezas hidrofilicas permanecen en el agua. El jabón forma asi un puente entre la fase acuosa y la fase grasa, dando lugar a la emulsión ${ }^{6}$. Los jabones sódicos y potásicos, que son muy solubles en agua pero escasamente solubles en grasas, formarían con las ceras emulsiones del tipo grasa en agua ${ }^{7}$ (fig. 5).

El secado de la pintura a la cera-jabón se producía por evaporación del agua contenida en la emulsión. Una vez seca, la pintura resistía bien la humedad, debido a que en su superficie habrían quedado las colas hidrófobas de las moléculas de jabón, con tendencia a repeler el agua. No obstante, un proceso mecánico de frotación en presencia de agua hacía que ésta

${ }^{3}$ Loumyer, G., 1914: Les Traditions Techniques de la Peinture Médiévale. Bruselas-Paris, 154160. Forbes, R. J., 1964: Studies in Ancient Technology. Leiden, 244.

${ }^{4}$ Neuburger, A., 1969: The Technical Arts and Sciences of the Ancients. Nueva York, 116-117.

5 Wigginton, E. (Ed.), 1972: The Foxfire Book. Garden City, N. Y., 151-158.

- Trotman, E. R., Dyeing and Chemical Technology of Textile Fibres. 5." ed., 193-197.

? Bailey, A. E., 1951: Industrial Oil and Fat Products. Nueva York, 337. 


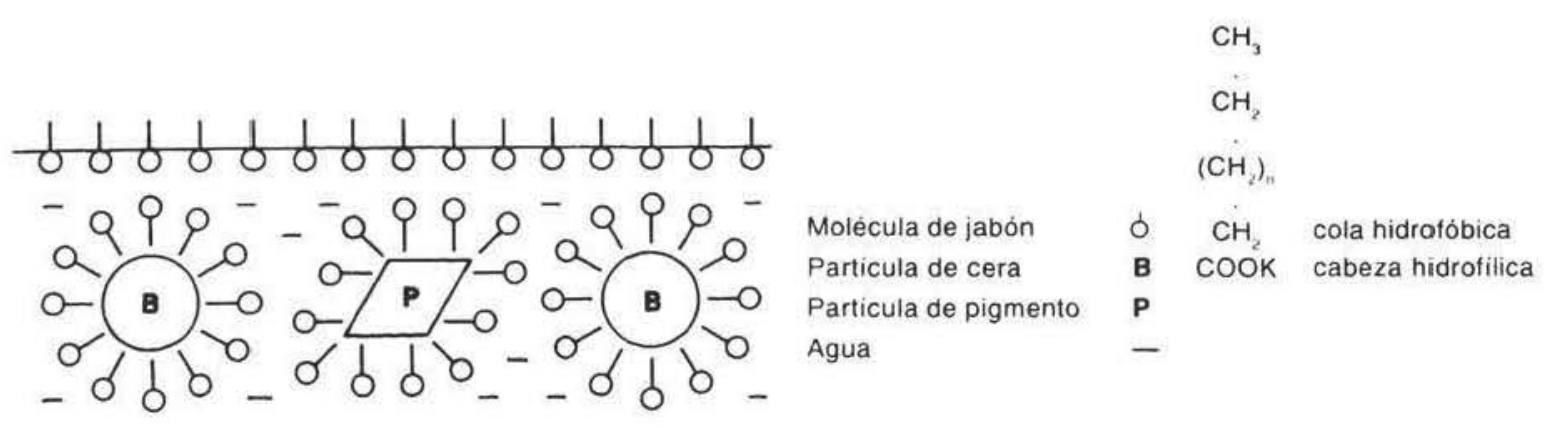

Figura 5.- Representación idealizada de la orientación de las moléculas de jabón en la pintura a la cera-jabón.

penetrase en el aglutinante y que la pintura perdiera consistencia. El secado de la pintura era por tanto reversible, caracteristica que coincidia con lo observado en los murales de Mérida.

La evaporación del agua provocaba la contracción de la pintura. El jabón sódico no parecía capaz de absorber suficientemente dichas contracciones: los ensayos efectuados con películas de cera de abejas y jabón sódico aplicadas sobre soporte de vidrio mostraban grietas y falta de adherencia, indicios de la escasa cohesión de esta emulsión como aglutinante.

El jabón potásico, por el contrario, formaba con la cera de abejas un aglutinante que se mantenía flexible durante el secado y la pintura resultante no se agrietaba. Las películas de pintura compuestas por una emulsión de cera de abejas y jabón potásico mezclada con diversos pigmentos y aplicada sobre vidrio, muro estucado, tabla, lienzo y papel, mantenían una firme adherencia al soporte tras el secado.

Esta materia pictórica mostraba la facilidad de manejo y la velocidad de secado propias de otras emulsiones acuosas, como los temples, con la ventaja adicional de que admitía fuertes empastes sin pérdida de cohesión.

Otras características de la pintura a la cera-jabón eran la transparencia de tonos, la luminosidad del colorido, el cuerpo de la pincelada, de trazo blando con rebordes abultados, y la configuración de pequeños cráteres que aparecian con frecuencia en la superficie de los colores debido a las burbujas que quedaban atrapadas en la pintura al diluir con agua dicha materia jabonosa (fig. 6 y 7). El acabado natural de la pintura era mate, pero adquiria un brillo suave al frotarla con un paño.

Con el fin de determinar si se habían utilizado jabones sódicos o potásicos en las muestras romanas, se llevó a cabo un análisis elemental sobre muestras sin tratar con un JEOL JXA840A Scanning Electron Microscope con Tracor Northern TN-550a Energy Dispersive X-ray Analysis System.

Los análisis detectaron en la pintura una cantidad de potasio elevada y ausencia de sodio, en consonancia con la hipótesis de que el aglutinante debiera haber sido elaborado con lejías potásicas (fig. 8). También mostraron la constante presencia del calcio, en concordancia con los análisis de infrarrojos, que ya habían detectado carbonato cálcico en la composición de los estratos pictóricos (figs. 3.1, 3.2). 


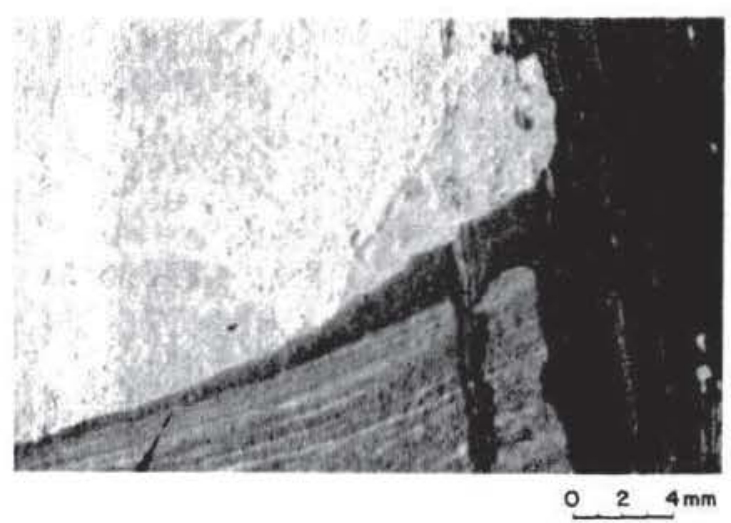

Figura 6. Detalle de una pintura a la cerajabón. Se observan los caracteristicos cráteres de las zonas empastadas.

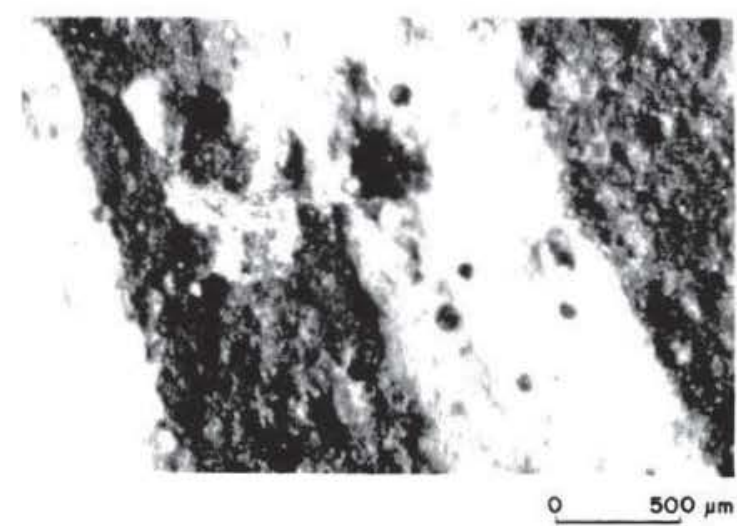

Figura 7. Detalle de la superficie de la muestra Merida 2. Resulta notoria la similitud de aspecto que presentan estos empastes con los de la figura anterior.

11 carbonato cálcico podria proceder de cal que hubiera sido añadida al aglutinante, o de mineral calizo introducido como carga en la preparación de la pintura.

Para valorar la incidencia de la cal y del carbonato cálcico en la emulsión cera-jabón, se efectuó una serie de ensayos de laboratorio. Primeramente se estudiaron diversas combinaciones de cal con proporciones variables de cera, jabón y diversos pigmentos. En todas las pruebas la incorporación de la cal hizo que se rompiera la emulsión y que ésta no pudiera emplearse con fines artisticos. La hipótesis de que el carbonato cálcico de las muestras hubiese sido añadido a la pintura en forma de cal parecía quedar descartada.

La segunda hipótesis se estudió comparando una serie de mezclas del aglutinante de cerajabón y diversos pigmentos, con una segunda serie en la que a las mezclas mencionadas se habia añadido calcita. De forma poco previsible, los colores con calcita resultaron más intensos y luminosos que los elaborados con pigmento puro.

También se comprobó que dichos ensayos que la saturación de color del aglutinante se efectuaba con una cantidad de pigmento relativamente pequeña en relación con técnicas como el óleo. La materia pictórica resultaba por esta causa excesivamente transparente y falta de cuerpo. Las pruebas en las que se aumentó la proporeión de pigmento mostraban una mejora de estas caracteristicas, pero la pintura se volvia mate, opaca y dificil de manejar.

Una nueva serie de ensayos permitió observar que el carbonato cálcico daba al artista la posibilidad de controlar el grado de transparencia y cuerpo de la pintura sin perjudicar su brillo y luminosidad. Por otra parte, la pintura con carbonato resultaba más dura tras el secado y admitía mucho mejor el bruñido.

Estas experiencias parecian indicar que el carbonato cálcico no deberia ser considerado como una simple carga, sino como parte fundamental en la formulación de la pintura, ya que suponia una mejora sustancial en las cualidades de la misma.

Los anteriores ensayos parecian confirmar la idoneidad técnica del aglutinante de cerajabón para pintura artistica. Aún asi podriamos preguntarnos si la presencia de estas sustancias 


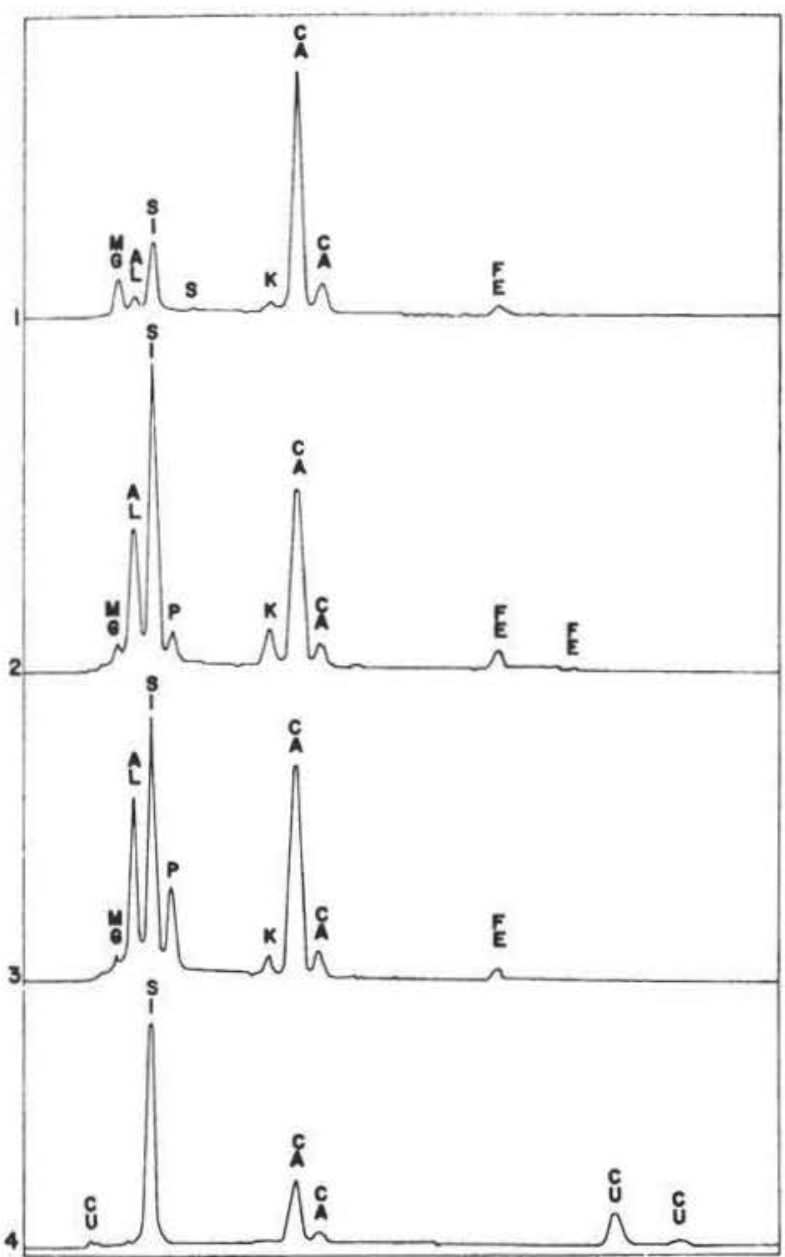

Figura 8. - Identificación elemental cualitativa. I: Estrato verde claro. Mérida I (comparar con figs. 1, 3.1). 2: Complutum 1. Composición elemental de la capa ocre. 3: Mérida 3. Zona sin pigmento azul. 4: Mérida 3. Cristal de azul egipcio.

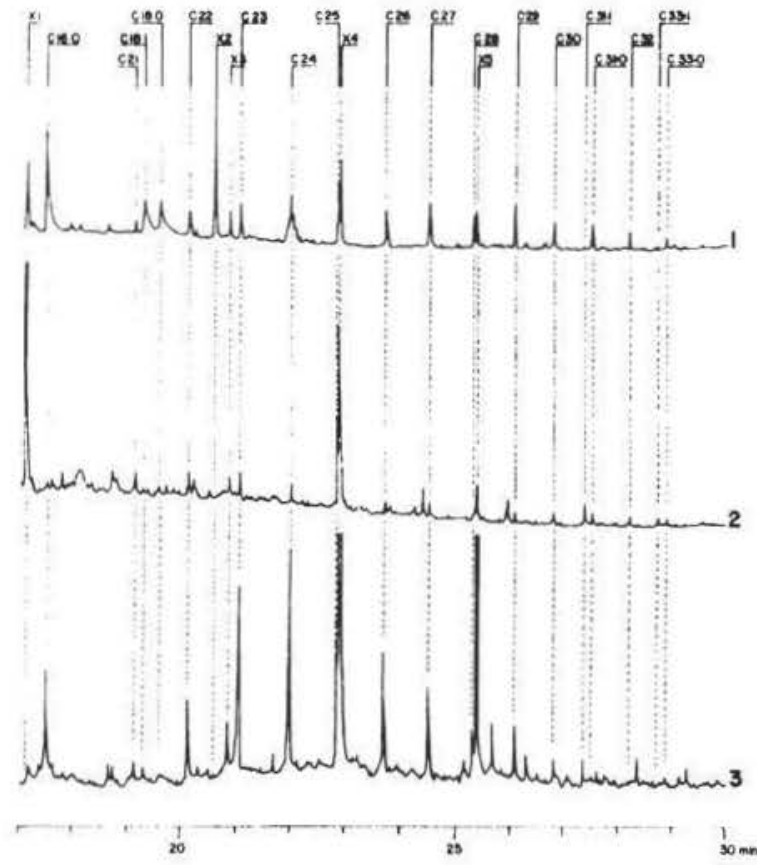

Picos

Compuestos

C16:0, C18:0, C18:1 Ácidos grasos libres.

C21-C 35 Hidrocarburos.

C $38-\mathrm{C} 50$

$\mathrm{X} 1, \mathrm{X} 2, \mathrm{X} 3, \mathrm{X} 5$

$\mathrm{X} 4$

Monoésteres de cadena larga. Posible contaminación - no identificada.

Dioctileftalato - contaminación.

Figura 9.-Estudio comparativo de la composición del aglutinante en muestras de Mérida, Complutum y Marsala. Disueltas en agua y tratadas con $\mathrm{HCl}$. 1: Mérida 3. 2: Complutum 1. 3: Marsala 1. Los cromatogramas muestran los picos de la cera de abejas y también de ácidos grasos.

no procedería de un tratamiento superficial que hubiese impregnado un estrato pictórico ejecutado el fresco.

Esta hipótesis, sin embargo, nos dejaria por explicar la propia hechura de los murales emeritenses, que incluyen múltiples veladuras y empastes con una técnica comparable a la de las pinturas de caballete y que parece exigir, por tanto, la intervención de un aglutinante matérico. Tanto el fresco como las distintas técnicas de coloreado de estucos que incorporan un bruñido final con ceras y jabones ${ }^{8}$, requieren que la coloración sea ejecutada con tintas muy

\footnotetext{
${ }^{8}$ Lade, K., Winkler, A., 1960: Yeseria y Estuco. Barcelona, 143-144.
} 
transparentes y de escaso cuerpo, muy poco apropiadas para reproducir los corpóreos rasgos de que hacen gala los murales estudiados.

\section{PRESENCIA DE LA TÉCNICA A LA CERA-JABÓN EN LA ANTIGÜEDAD}

En 1950 el quimico italiano Selim Augusti publicó el estudio químico más completo que se ha efectuado hasta la fecha para determinar la técnica pictórica empleada en la ejecución de los murales pompeyanos". Augusti analizó la composición química de la pintura en un gran número de muestras procedentes de Pompeya, correspondientes a los cuatro estilos. También analizó muestras de Herculano que no habian sufrido ningún proceso de limpieza o conservación.

Tras el examen visual y microscópico, Augusti consideró que los murales no fueron ejecutados al fresco, ni tampoco al temple o con técnicas mixtas. A través de exámenes microquimi$\cos$, Selim concluyó que la masa de todos los estractos pictóricos, tanto en los colores de fondo como en las capas superpuestas, estaba compuesta por cera de abejas, jabón potásico y carbonato cálcico, además del pigmento correspondiente al color del estrato.

A lo largo del presente estudio, los autores han analizado la composición de otras muestras de pintura mural romana: seis procedentes de Complutum y dos de Marsala. Esta vez se ha llevado a cabo un análisis simplificado, tendente únicamente a la detección de ceras y ácidos grasos, y prescindiendo del estudio compositivo capa por capa. Los ensayos previos y algunas de la reflexiones que comentaremos más adelante nos hicieron considerar que sería suficientemente significativa, en ciertos casos, la presencia de las mencionadas sustancias a la hora de determinar si la técnica de ejecución de una pintura mural había sido la emulsión de cera.

Las muestras fueron analizadas por cromatografia de gases, previa disolución del aglutinante y su tratamiento con $\mathrm{HCl}$ según el método explicado para la primera fase de las muestras de Mérida.

Nuevamente aparecieron las características configuraciones de picos de la cera de abejas, y las de los ácidos palmítico, esteárico y oleico (fig. 9). Estos resultados también estaban en concordancia con los obtenidos por Augusti en Pompeya, lo que parecía indicar la existencia de una técnica común para los cuatro enclaves considerados.

La uniformidad de técnica pictórica que presentaban unas pinturas murales tan separadas geográfica y temporalmente parecia indicar que el aglutinante de cera y jabón tenía un destacado lugar entre las técnicas pictóricas de la Antigüedad. El estudio de los textos antiguos ha convencido a los autores de que la técnica detectada no era otra que la técnica grecorromana de la encáustica.

\section{DISCUSIÓN}

Plinio informa en su Historia Natural que la encáustica era una materia pictórica a base de cera de abejas que se empleaba en pintura artística: "Ceris pingere ac picturam inurere quis primus excogitaverit non constat. Quidam Aristidis inventum putant postea consummatum a

\footnotetext{
${ }^{9}$ Augusti, S., 1950: La Tecnica dell Antica Pittura Parietale Pompeiana. Nápoles, 313-354.
} 
Praxitele, sed aliquanto vetustiores encaustae picturac exstitere, ut Polygnoti et Nicanoris ac Mnasilai Pariorum. Elasippus quoque Aeginae picturae suae inscripsit enékaen, quod profecto non fecisset nisi encaustica inventa" (no sabemos con certeza quién fue el primero en inventar el arte de pintar con cera y marcar a fuego la pintura. Algunos creen que fue inventado por Arístides, y más tarde llevado a la perfección por Praxiteles, aunque existen pinturas a la encáustica de fecha anterior, por ejemplo de Polignoto, de Nicanor y de Mnasilao de Paros. Elasipo de Egina también grabó en sus pinturas "lo pintó a la encáustica», lo que no hubiese hecho antes de la invención de la encáustica) "'.

Las palabras de Plinio inurere (de inuro, marcar con un hierro candente) e inscripsit (de inscribo, grabar), pueden relacionarse con la costumbre griega de imprimir sellos como firma de autoria o propiedad ". Podríamos pensar que los pintores griegos no firmaban sus obras con pincel al modo actual, sino que, como hacían con cartas y documentos, estampaban su sello sobre la cera coloreada. Esta hipótesis toma consistencia con el comentario final del mencionado párrafo de Plinio acerca de la inscripción de Elasipo, que quizás Plinio alcanzase a ver estampada en el cuadro, y cuyo texto completo fuese probablemente Elasippos enékaen. Esta estructura es similar a la empleada por los ceramistas griegos para firmar sus obras, del tipo Euphrónios égrapse (Eufronios lo grabó con un punzón) ${ }^{12}$, y también Exékias epoiese (Exequias lo hizo) $)^{13}$.

Dos sellos del artista griego del siglo v a. C. Dexamenos, que llevan la inscripción Dexámenos epoie ${ }^{14}$, vienen a apoyar el uso del sello como firma de la obra. Los sellos que se utilizasen para firmar encáusticas deberian ser diferentes a los empleados para lacrar, ya que tendrian que aplicarse en caliente sobre las ceras endurecidas de la pintura. Por tanto, serian probablemente de metal y dispondrian de mango.

Entre los utensilios empleados por los pintores antiguos figuraba uno cuyo uso se desconoce. Su nombre sugiere que se aplicaba en caliente: el cauterio. Leemos en un documento del jurista Marciano: "Item pictoris instrumento legato, cerae, colores similiaque horum legato cedunt, item peniculi et cauteria et conchaen (cuando se deja en herencia el instrumental de un pintor, las ceras, los colores y cuanto tiene que ver con esto, forman parte del legado, así como también los pinceles, los cauterios y las conchas) ${ }^{15}$. Un texto de Tertuliano parece apoyar la idea del cauterio como firma del pintor. Hablando del pintor Hermógenes dice que era «bis falsarius, et cauterio et stilo» (dos veces falsario, una por el cauterio y otra por el estilo) ${ }^{16}$.

De la encáustica sabemos también que podia ser aplicada tanto a espátula como a pincel. En el párrafo de Plinio que sigue al ya mencionado leemos «Pamphilus quoque Apellis praeceptor non pixisse solum encausta sed etiam docuisse traditur Pausiam Sicyonium primum in hoc genere nobilem. Bryetis filius hic fuit eiusdemque primo discipulus. Pinxit et ipse penicillo parietes Thespis, cum reficerentur quodam a Polygnoto picti» (dice la tradición que Pánfilo, el maestro de Apeles, no solo pintó a la encáustica, sino que también enseñó a Pausias de Sición,

\footnotetext{
${ }_{10}$ Plin. $\mathrm{NH} 35,122$.

"Boardman, J., 1970: Greek Gems and Finger Rings. Londres, 13.

12 Corpus Vasorum Antiquorum, 1923. Paris. 1, 3 Ic, 4.

13 Corpus Vasorum Antiquorum, 1926. Paris. 4, $3 \mathrm{He}, 19$.

14 Boardman, J., Op. cit. 287.

is Martian., dig. 33, 7, 17, 1.

16 Tert., adv. Hermong. 1, 126.
} 


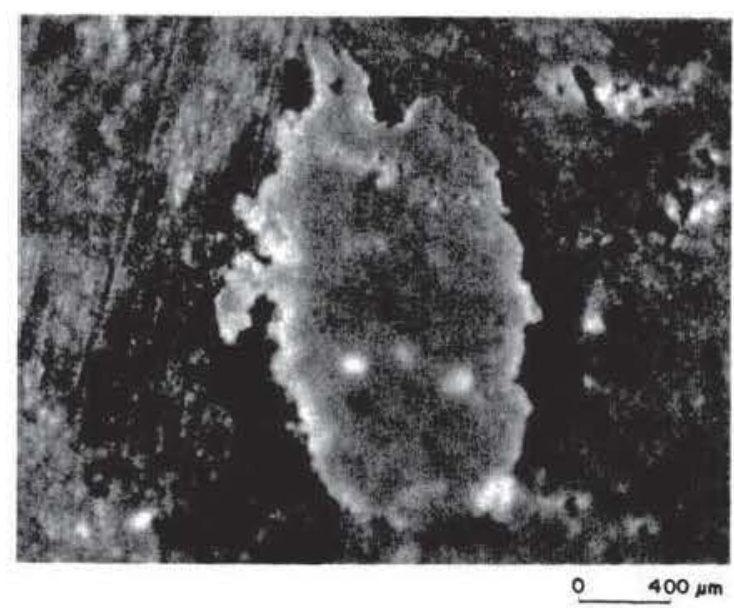

Figura 10. Sección paralela a la superficie a través del estrato pictórico de una obra ejecutada a la cera-jabón sobre lienzo. Sobre el fondo general de color se destacan manchas oscuras de aspecto graso que no parecen resultar miscibles con los pigmentos, asi como otras menores. transparentes o amarillentas.

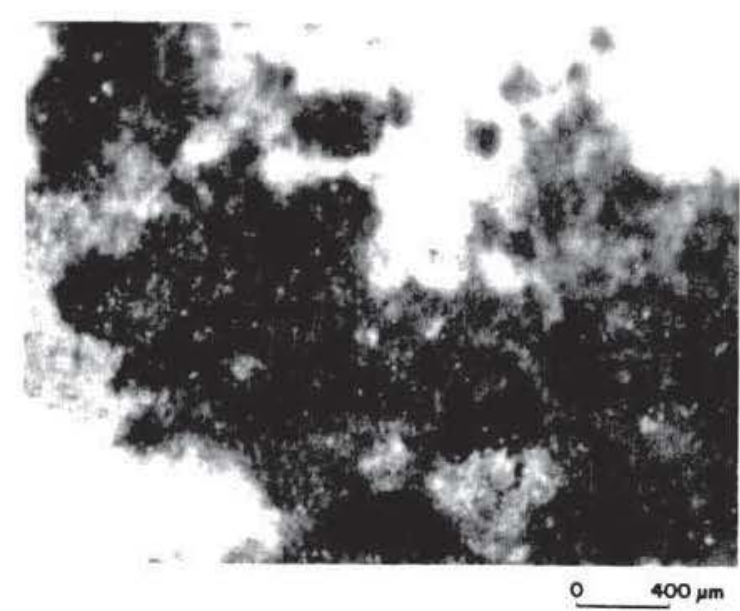

Figura 11. Sección paralela a través del estrato pictórico de la muestra Marsala 1. La zona blanca corresponde al mortero. Son apreciables manchas grasas oscuras, amarillentas y transparentes.

el primer maestro reconocido en su estilo. Pausias era hijo de Brietes, con quien habia estudiado en sus comienzos. Él también pintó con pincel algunos murales en Tespis, que habian sido pintados originalmente por Polignoto y necesitaban ser restaurados) ${ }^{17}$. Un poco más adelante comenta Plinio acerca de la pintora Jaya de Cícico «penicillo pinxit et cestro in ebore» (pintaba con pincel, y con espátula sobre marfill) ${ }^{18}$. Cierra Plinio el libro XXXV dedicado a la Pintura con un ambiguo párrafo que no parece sino insistir en que la encáustica era una pintura a base de cera, y que sobre marfil se solia aplicar con espátula. «encausto pingendi duo fuere antiquitus genera, cera et in ebore cestro, id est vericulo" (dos fueron los métodos de pintura a la encáustica en la Antigüedad, a la cera y sobre marfil con un cestro o vericulo) ${ }^{19}$. Gracias al estudio de Cross y Henry sobre la encáustica grecorromana podemos deducir que ambas denominaciones, cestro y vericulo, corresponden a espátulas ${ }^{20}$. Los retratos funerarios de El Fayum son magníficos ejemplos de la aplicación de la encáustica según estos dos métodos. En dichos retratos es frecuente encontrar las carnaciones ejecutadas a espátula y los ropajes a pincel $^{21}$.

El párrafo de Plinio continúa: «donec classes pingi coepere. Hoc tertium accessit resolutis igni ceris penicillo utendi, quae pictura navibus nec sole nec sale ventisque corrumpitur»

17 Plin., HN. 35, 123.

ix Plin., HN. 35, 147.

19. Plin., HN. 35, 149.

20 Cros, H., Henry, C., 1884: L'Encaustique et les autres Procédés de Peinture chez les Anciens. Paris, 12-14, 26-34.

${ }^{21}$ Coche de la Ferté, E., 1952: Les Portraits Romano-Égyptiens du Louvre. París. 11-12. 

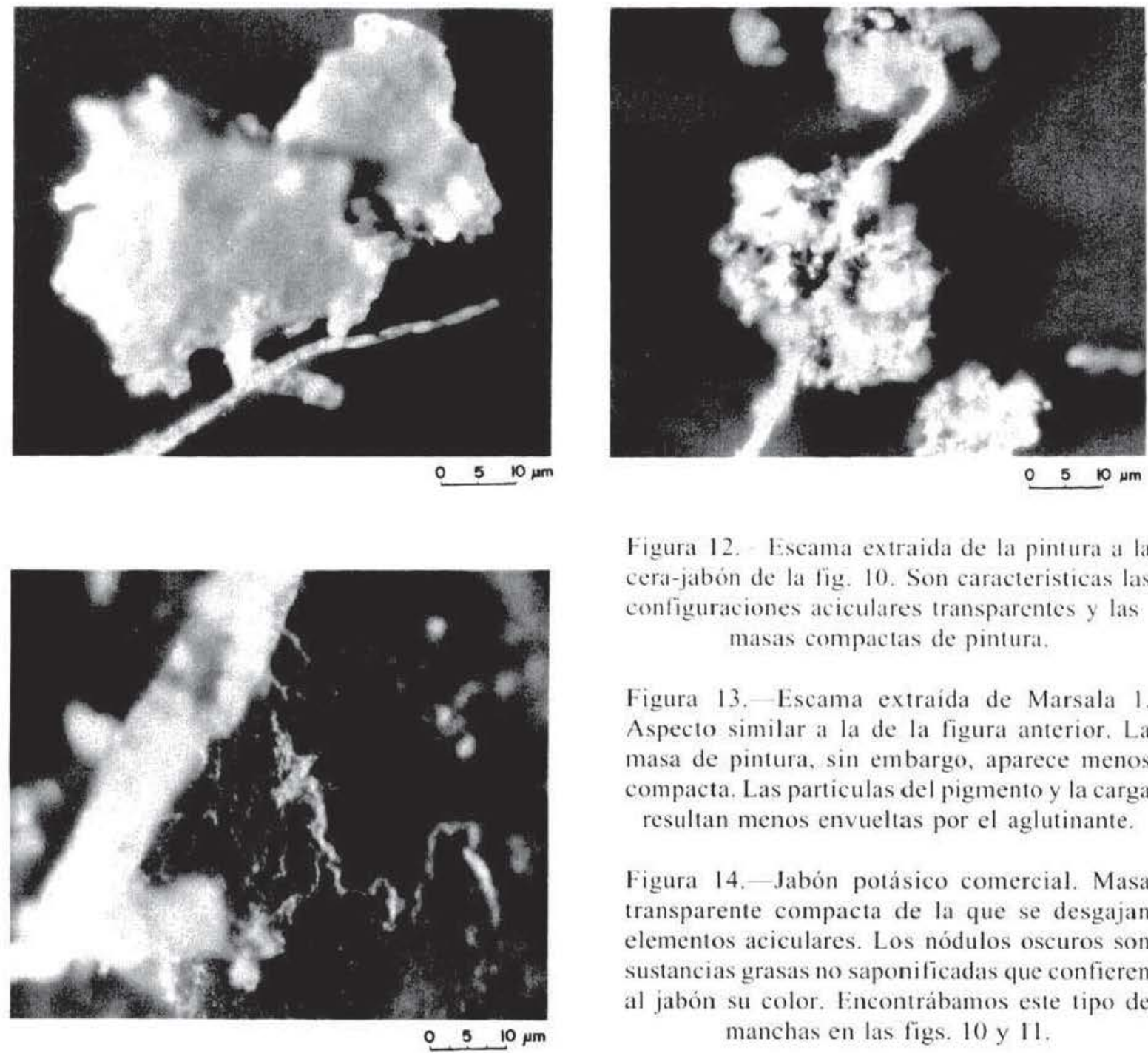

Figura 12. Escama extraida de la pintura a la cera-jabón de la fig. 10. Son caracteristicas las configuraciones aciculares transparentes y las masas compactas de pintura.

Figura 13. - Escama extraida de Marsala 1. Aspecto similar a la de la figura anterior. La masa de pintura, sin embargo, aparece menos compacta. Las particulas del pigmento y la carga resultan menos envueltas por el aglutinante.

Figura 14.-Jabón potásico comercial. Masa transparente compacta de la que se desgajan elementos aciculares. Los nódulos oscuros son sustancias grasas no saponificadas que confieren al jabón su color. Encontrábamos este tipo de manchas en las figs. 10 y 11 .

(cuando se empezó a pintar las naves de guerra se añadió un tercer método, en el que la cera derretida era aplicada con pincel. Esta pintura no se ve afectada en las embarcaciones por la acción del sol, de las sales o del viento).

Como parece quedar claro que este tercer método, en el que las ceras coloreadas se aplicarian en caliente, era utilizado para pintar barcos, podriamos considerarlo al margen de este estudio dedicado a técnicas artisticas.

La anécdota de la visita de Apeles a Protógenes ${ }^{22}$ indica que la pintura para artistas estaba siempre lista para su uso y era de fácil manejo, lo que confirma que sus características eran bien distintas a las de la cera fundida de la pintura para embarcaciones. El mismo hecho de que la encáustica artística pueda ser aplicada exclusivamente con pincel abunda en este concepto: en los ensayos llevados a cabo con cera fundida y pigmentos se observaba que la cera se

22 Plin. HN. 35, 81-83. 


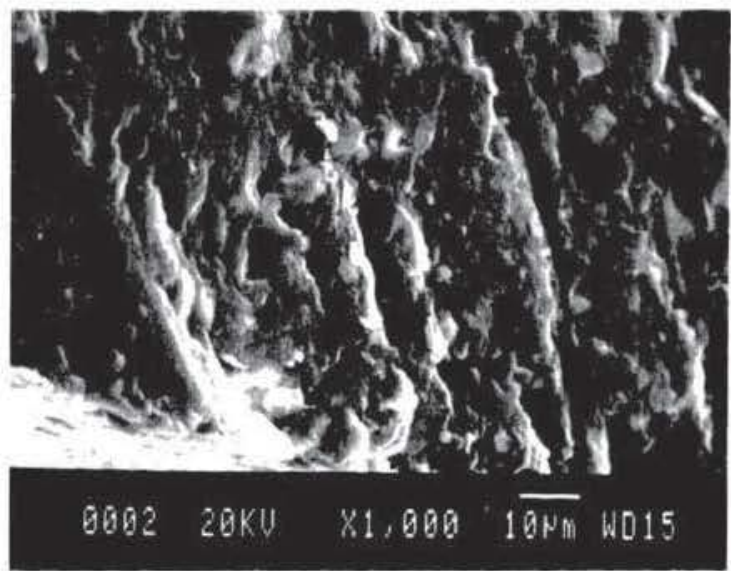

Figura 15. Fractura de la muestra de pintura a la cera-jabón de la fig. 10.

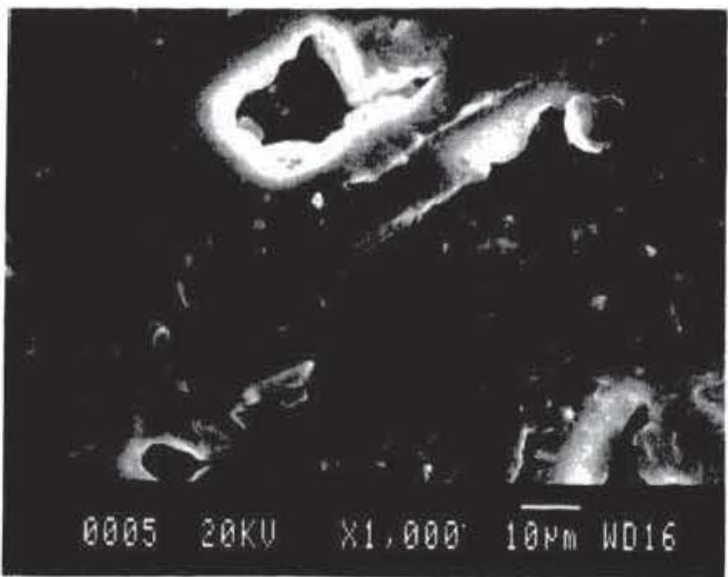

Figura 17.-Estratigrafia de la pintura a la cerajabón de las fig. 10 y 15. Las oquedades que aparecen en el interior se formaron durante el proceso de secado.

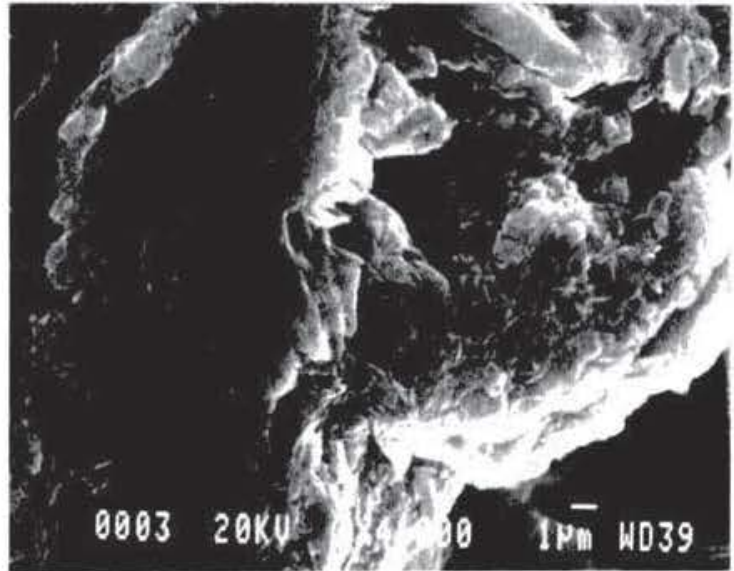

Figura 16. Fractura del fragmento de pintura azul Mérida 3. Configuración escamosa similar a la de la figura anterior, aunque de menor cohesion.

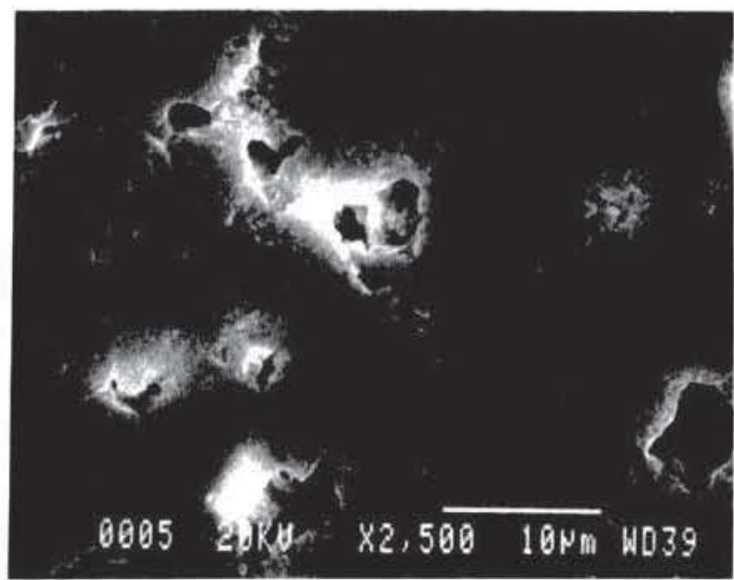

Figura 18. Estratigrafia de la pintura mural romana de la fig. 2 .

endurecia al llegar al soporte y se apelmazaba en el pincel, lo que hacía impracticable su empleo como material artístico. Los experimentos realizados con espátulas calientes tampoco ofrecieron una solución a la ejecución de las obras. La superposición de veladuras y las finas pinceladas de la pintura pompeyana no eran reproducibles por este sistema. Estas experiencias parecian indicar que la cera debia haber sido aplicada en frio y que podia ser diluida con un vehiculo. 
La cera de abejas puede permanecer liquida a temperatura ambiente en emulsión acuosa o disuelta en un aceite volátil. Esta última posibilidad debe ser descartada, pues aunque este tipo de disolventes ya era conocido en los tiempos de la Grecia arcaica, nunca pareció haber sido empleado en pintura ${ }^{23}$.

El propio nombre de encáustica es indicativo de que la cera se encontraba en forma de emulsión. Encáustica procede del griego enkaustikós, de en en, y kaustikós, sustancia que quema y destruye los tejidos vivos que se ponen en contacto con ella ${ }^{24}$. Cera en-cáustica sería pues cera tratada con un sustancia cáustica, es decir, cera en emulsión.

Los textos de Sereno Samónico ${ }^{25}$ indican que los romanos conocian la propiedad de la cera de convertirse en emulsión por acción de la lejía.

Algunos autores han considerado que la cera saponificada con sosa era la cera púnica de la que hablaban los textos antiguos sobre pintura, y dedujeron en consecuencia que había sido empleada como aglutinante.

Los textos de Dioscórides y Plinio que describen la preparación de la cera púnica explican que la cera amarilla, tras haber sido expuesta al sol, era repetidamente hervida en agua de mar con nitro ${ }^{26}$. La traducción del nitrum romano por natron (sosa), ha sido el origen de la confusión sobre la naturaleza de la cera púnica.

Vicente Requeno, ya en el siglo xvIII, demostró que el nitrum no era otra cosa que el nitro actual, es decir, nitrato potásico ${ }^{27}$. Los ensayos experimentales mostraron que al hervir la cera de abejas con nitrato potásico ésta no se saponificaba; únicamente se blanqueaba. Este mismo efecto se producía al hervir la cera con cloruro sódico (agua de mar). Dichas experiencias parecen dejar claro que la cera púnica era cera de abejas blanqueada por un proceso químico. El mismo Plinio coloca la cera púnica a la cabeza de las distintas calidades de cera, sin hacer otra distinción que su grado de pureza ${ }^{28}$.

Conviene considerar por otra parte que la cera emulsionada con un alcali no es suspectible de ser empleada como aglutinante. Los ensayos llevados a cabo tanto con sosa como con potasa dejaron patente que la emulsión de cera resultante carecía de cohesión, y la pintura resultaba pulverulenta y quebradiza. A esta emulsión le hacía falta un plastificante. Éste era el papel del jabón potásico.

El jabón potásico era un producto bien conocido por los romanos. Dioscórides describe su preparación con aceite o sebo y ceniza de sarmiento ${ }^{29}$, y Plinio recomienda el jabón de sebo de cabra y cenizas de haya ${ }^{30}$.

$\mathrm{Al}$ imaginar ahora la encáustica como una emulsión de cera y jabón, que tiene un secado reversible, resulta lógico que los griegos utilizaran otro tipo de pintura en las embarcaciones que no se fuera con el agua.

${ }^{23}$ Loumyer, G., Op. cit. 153-160.

${ }^{24}$ The Oxford English Dictionary, 1961. Oxford.

${ }^{25}$ Ser Samm. Med., 44, 7.

${ }^{26}$ Dioscorides, 2, 105. Plin. HN. 28, 84.

27 Requeno, V., 1782: Saggi sul Ristabilimento dell Antica Arte de Greci e Romani Pittori. Parma, II, 131-266.
${ }^{28}$ Plin. HN. 28, 83.
${ }^{29}$ Dioscorides $5,93$.
${ }^{30}$ Plin. HN. 28, 51. 

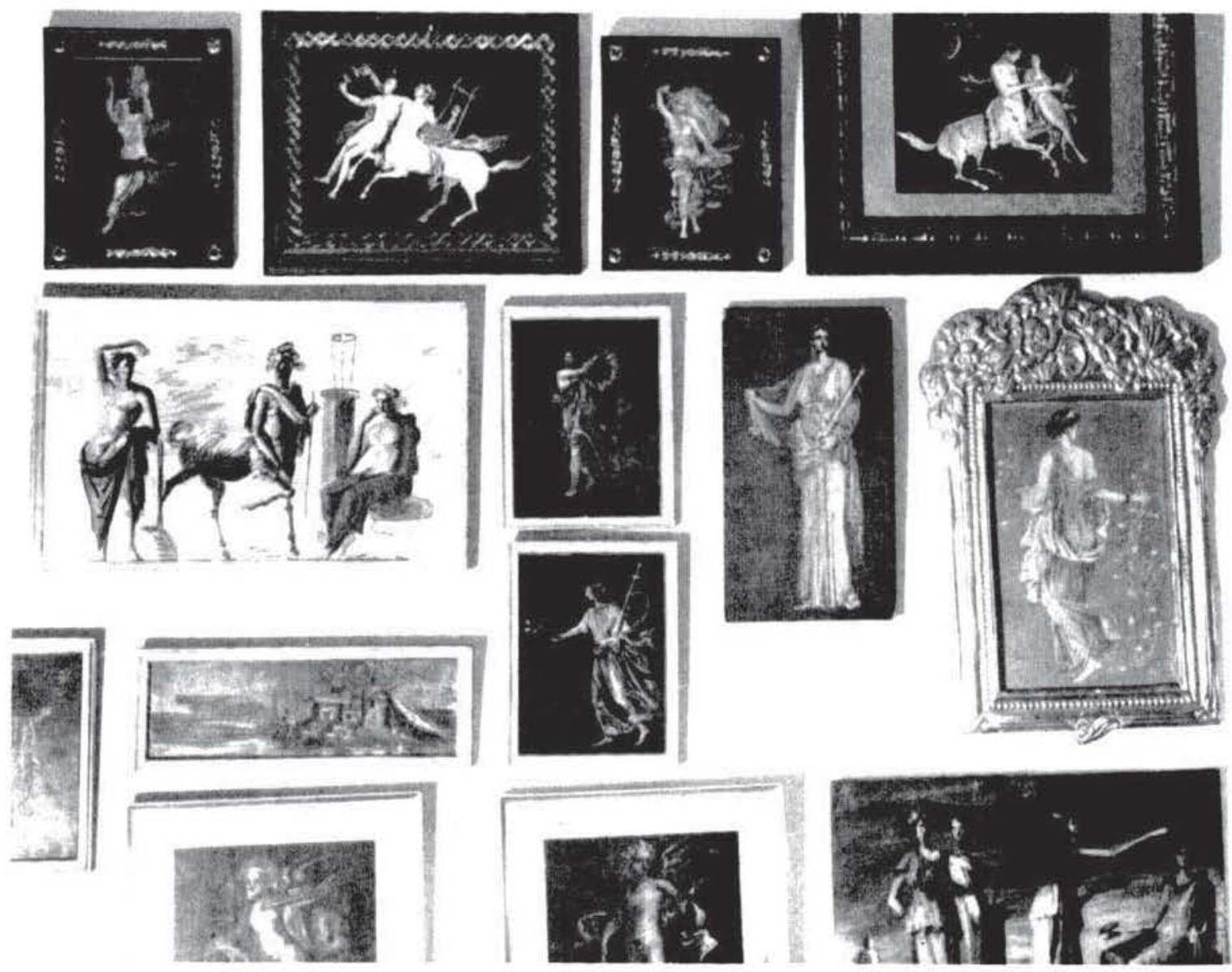

Figura 19. Copias a la cera-jabón de pinturas romanas conservadas en el Museo de Nápoles.

De hecho, la pintura seca a la cera-jabón puede eliminarse con una esponja húmeda. Esta es una de las caracteristicas de la pintura griega que ha sido comentada por Esquilo, Platón, Euripides y Antifon ${ }^{31}$. El suceso relatado por Plinio en el que Protógenes pinta la boca espumeante de un perro lanzando su esponja llena de color ${ }^{32}$ muestra además de forma gráfica que la pintura era una materia jabonosa.

Aunque Plinio no dice expresamente que Protógenes pintaba a la encáustica, sí cuenta que Pánfilo, maestro de Apeles, pintaba con esta técnica, por lo que su discipulo la habria aprendido. La anécdota del cuadro pintado a medias por Apeles y Protógenes muestra que ambos utilizaban una técnica común cuyas caracteristicas parecen coincidir con las de la cera-jabón.

Para poder valorar la extensión del uso de la téenica a la cera en la pintura grecorromana debemos considerar que la encáustica es el único procedimiento citado por Plinio en relación con pintura artística. Otros autores grecorromanos se refieren también al uso habitual de la

\footnotetext{
3 Forbes, R. J., Op. cit. 251.

32 Plin. HN. 35, 102.
} 


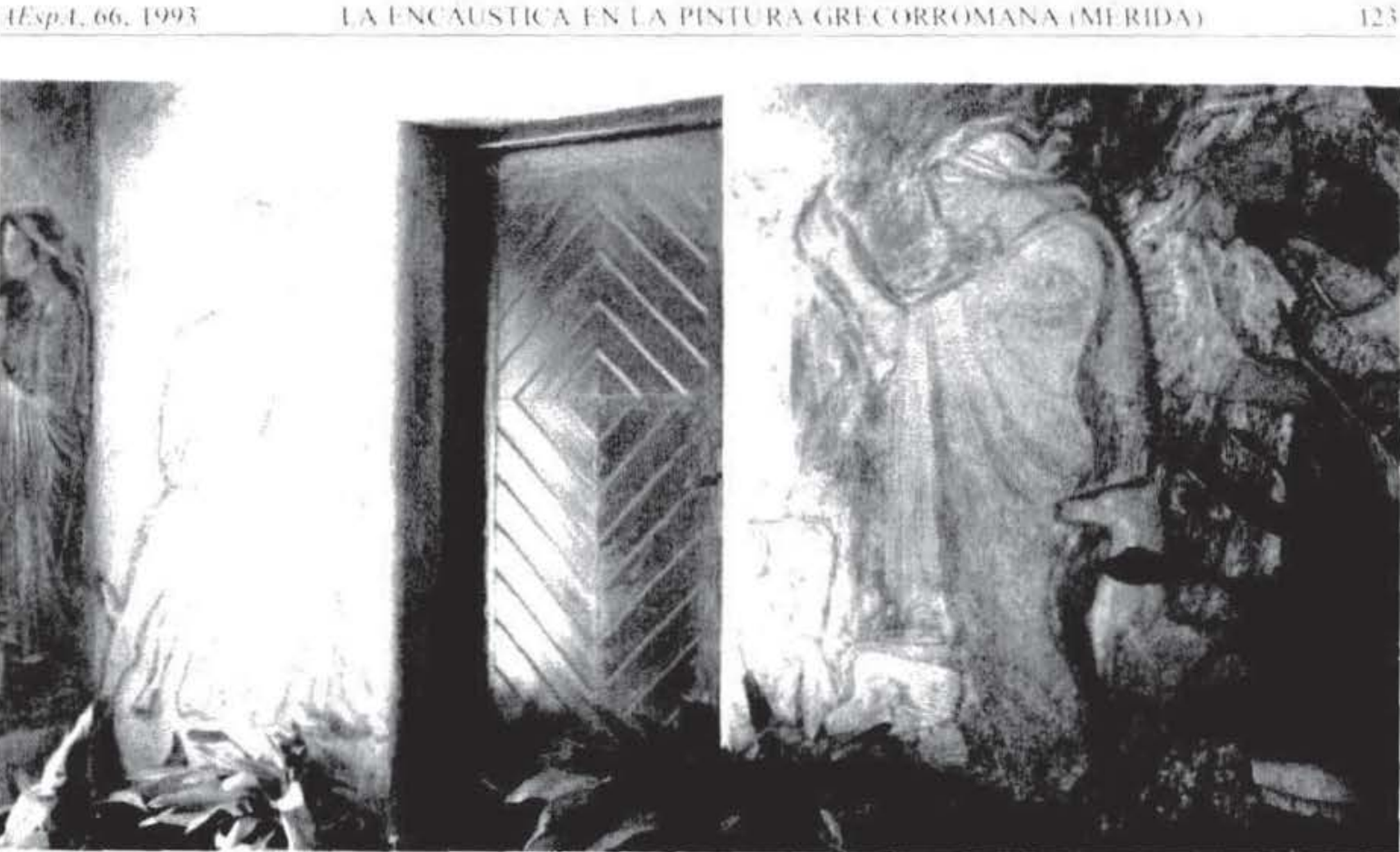

Figura 20. Pintura mural ejecutada a la cera-jabon por Jose Cuni en 1964. Iistado actual. La tecnica a la cera-jabón permite una sencilla ejecución de grandes superficies murales y tiene una magnifica conservacion.

encáustica en la Antigüedad ${ }^{3 .}$. Esta técnica parecia estar tan extendida que en algunos casos la palabra cera era utilizada como sinónimo de pintura ${ }^{4}$.

Diremos para finalizar que incluso la Biblia apoya la idea del uso generalizado de la encáustica en la decoración mural de los edificios. En el Libro de los Macabeos, escrito en griego en el siglo ॥ a. C. leemos: "de la misma forma que el arquitecto de un edificio nuevo tiene que ocuparse de toda la estructura mientras quien se encarga de decorarla con pinturas a la encáustica debe buscar lo que es apropiado a la ornamentación” ${ }^{75}$.

\section{CONCLUSIONES}

Los estudios quimicos de las muestras de pintura mural romana examinadas sugieren de forma fehaciente que los pigmentos se encontraban fijados al soporte medio de un aglutinante compuesto por cera de abejas y jabón potásico. Los exámenes microscópicos revelaron una

3 Varro Rust., 3, 17. Pollux Onom., 7, 28, 128. Anastasius Ant., M 89, 1405 A. Boetius; Inst. Arithmeth. Praef, 4. Const. Diac. Laud., M 88 479-527. Vitr., 4, 2. Severus Alex., Ducange, Glossarium mediae et infimae graecitatis, 648. Ath. Deipn., 5, 200 a. Luc, Im., 23. Prud. c, Symm., 2, 39-48. Paul. Nol. Ep. ad Sulp. Sev., 30. Eus. VC., 1, 3, 8. Ov. Fast., 3, 831. Mart. Epigr., 4, 47. Procop. Aed., $1,10$. Auson. Epigr., 26. Stat. Silv., 1, 100. Reinach, A., 1921: Recueil Milliet. Texts Grecs et Latins relatifs à l'Histoire de la Peinture Ancienne. Paris, 18.

${ }^{34}$ Sen. Ep., 4, 121, 5. Anacreontica, 28, 29, 32, 48. Anthologia Graeca 4, 9, 9.

${ }^{34}$ Abel, M., 1949: Le Livre des Maccabées. Paris, 313-314. 
gran similitud entre la configuración de las muestras romanas y las de pintura a la cera-jabón (figs. 3, 4, 10-13, 15-18). Por último se comprobó que los rasgos de ejecución característicos de la pintura romana podian ser reproducidos con gran fidelidad con la técnica de la cera-jabón (fig. 19).

Los datos aportados por los textos antiguos acerca de la composición y caracteristicas de la técnica grecorromana de la encáustica parecen indicar que los murales de Mérida y Complutum estudiados, y también las pinturas pompeyanas analizadas por Augusti, fueron ejecutados con dicha técnica. Estas conclusiones siguieren que dicho procedimiento pictórico tenian un uso mucho más generalizado de lo que se consideraba hasta la fecha, y por tanto más acorde con la importancia concedida a la encáustica en los textos griegos y latinos.

La confirmación de estas hipótesis haría necesaria una revisión en profundidad de las teorías que consideran el fresco como la técnica pictórica habitual en el mundo romano.

\section{AGRADECIMIENTOS}

Jorge Cuní quiere agradecer la ayuda prestada a este proyecto por: Walter H. Hopwood, por los análisis por F.T.I.R. y las diversas soluciones que proporcionó para el desarrollo del estudio analítico. W. David Erhardt y Enrique Parra, por la orientación del trabajo analítico y los análisis por C.G., E.M. y F.T.I.R. José Joaquín Caerols, por su colaboración en la traducción de los textos griegos y latinos. Ricardo Olmos y Marion F. Mecklenburg, por su apoyo al proyecto. Roland $\mathrm{H}$. Cunningham, por su colaboración en los trabajos de estratigrafía y microfotografia. Melanie T. Feather, por los análisis por S.E.M. Juan Altieri y Antonio Méndez, por la cesión de las muestras antiguas. Eileen Lynch, por sus sugerencias y constante apoyo. Y al Ministerio Español de Educación y Ciencia/Comisión Interministerial de Ciencia y Tecnología por su ayuda en la financiación y coordinación de este proyecto.

\section{APÉNDICE: MUESTRAS ANALIZADAS}

MÉRIDA 1 Fragmento de mortero que incluye restos de pintura con representación vegetal. Casa del mitreo. Mérida. Primera mitad del siglo II d. C.

MÉRIDA 2 Fragmento de pintura mural sobre mortero de cal. Decoración con peces. Fondo negro y azul sobre el que aparecen líneas amarillas y empastes blancos. Casas de la cripta del museo, Mérida. Primera mitad del siglo II d. C.

MÉRIDA 3 Fondo liso de color azul sobre mortero. Casa del mitreo, Mérida.

COMPLUTUM 1 Mortero pintado con fondo ocre claro sobre el que aparece trazada una línea blanca. Villa del Val, Complutum. Finales del siglo III d. C.

MARSALA 1 Mortero con capa de pintura lisa en color rojo óxido y empastes superpuestos en forma de hojas en ocre amarillo. 